\title{
A new specific assay for the detection of DNA immune complexes: its relevance in SLE
}

\author{
P. KLEMP, ${ }^{1}$ O. L. MEYERS, ${ }^{1}$ AND E. H. HARLEY ${ }^{2}$ \\ From the ${ }^{1}$ Rheumatic Diseases Unit and ${ }^{2}$ Department of Chemical Pathology, University of Cape Town, \\ South Africa
}

SUMmARY Double-stranded DNA immune complexes (DNA-ICs) were assayed by millipore filtration and deoxyribonuclease digestion in 40 patients with both active and inactive systemic lupus erythematosus (SLE). The assay is superior to the double-stranded DNA antibody (ds ADA) as an indicator of active disease, and, when combined with the total haemolytic complement $\left(\mathrm{CH}_{50}\right)$ and ds ADA levels it increases the prediction of the relative risk of active disease. A good correlation between actual levels of DNA-ICs and the degree of activity was also shown. We conclude that measurement of DNA-ICs is of value as an additional monitor in the assessment of activity in SLE.

A number of laboratory tests are available for the diagnosis of SLE and for the assessment of activity. ${ }^{1-8}$ The most useful diagnostic test is the demonstration of increased concentrations of ds ADA, because with rare exceptions it is found exclusively in SLE. A normal ADA level, however, does not exclude the diagnosis. Depression of $\mathrm{CH}_{50}, \mathrm{C} 3, \mathrm{C} 4$, and elevated ADA levels are highly suggestive, but not invariable, indicators of active lupus. The observation of abnormal values for the above in the absence of apparent clinical activity may be due to an inabiity to recognise minor grades of activity at the bedside. Methods exist for the detection of antigen nonspecific immune complexes, ${ }^{9-21}$ but there are few assays for detecting complexes to specific antigens. ${ }^{22-24}$

A new technique for the detection of DNA-ICs based on the principle of millipore filtration and deoxyribonuclease digestion has been shown to be highly specific for SLE ${ }^{25}$ This study was designed to evaluate the latter in the following terms: (1) as a monitor of disease activity; (2) whether the presence of DNA-ICs in the circulation in the absence of clinical activity heralds the onset of active disease; (3) the relationship between actual levels of DNA-ICs and the severity of the acute episode.

Accepted for publication 8 April 1982.

Correspondence to Dr P. Klemp, Rheumatic Diseases Unit, Department of Medicine, University of Cape Town, Observatory 7925, South Africa.

\section{Materials and methods}

PATIENTS

Forty patients with SLE were studied prospectively. They were selected from the wards and from the Lupus Clinic at Groote Schuur Hospital. Patients were selected so as to include a wide spectrum of organ involvement during both active and inactive phases of the disease. There were 37 women and 3 men, 27 were Cape Coloured ${ }^{26} 8$ were Caucasian, and 5 were Negro. Their ages ranged from 15 to 54 years (mean 30). Eight were studied during the initial presentation of SLE, while in the remaining 32 patients the duration of the disease ranged from 1 to 26 years (mean 5.9$)$. Thirty-seven patients $(92.5 \%)$ satisfied the preliminary ARA criteria for the classification of SLE. ${ }^{27}$ The remaining $3(7 \cdot 5 \%)$ were considered to have unequivocal evidence of SLE on the following grounds. One patient presented with acute polyarthritis, an erythematous butterfly rash, pericarditis, fever, severe depression, hypocomplementaemia, positive antinuclear antibody (ANA) and elevated ADA levels. The second had a longstanding history of nondeforming polyarthritis, neuropsychiatric symptoms, a butterfly rash, positive ANA, hypocomplementaemia, ADA elevation, and granular casts on a number of occasions. The third patient presented with generalised cutaneous vasculitis, polyarthritis, alopecia, positive ANA, and ADA elevation. The patients were assessed at each 
visit for evidence of clinical activity. The manifestations considered to be indicative of active SLE are shown in Table 1. Flares were classified as minor, major, or life-threatening. A flare was judged to be minor if nonsteroidal anti-inflammatory agents were sufficient to control musculoskeletal symptoms or if skin lesions could be adequately controlled with topical corticosteroids. Major flares usually required admission to hospital and almost invariably corticosteroid and/or immunosuppressive therapy to control the flare. Episodes were considered to be lifethreatening in those patients who presented with severe fulminating cerebral, renal, or multisystem disease and who were often unresponsive to therapy.

\section{LABORATORY TESTS}

At each visit urine was examined chemically and microscopically, and blood was drawn for: $\mathrm{CH}_{50}$, assayed by a modification of the method of Kent $e t$ al. ${ }^{28}$ Anti-DNA antibody (ADA) was measured in serum stored at $-20^{\circ} \mathrm{C}$ by the millipore filtration technique essentially as described by Ginsberg and Keiser. ${ }^{29}$ The normal range for our laboratory is between 0 and $5 \mu \mathrm{g}$ DNA bound $/ \mathrm{ml}$ serum. Levels of 5 to 15 are regarded as suggestive, while levels above $15 \mu \mathrm{g}$ DNA bound/ml are virtually diagnostic of

Table 1 Criteria used in the assessment of disease activity in $S L E$

\begin{tabular}{|c|c|c|}
\hline $\begin{array}{l}\text { Organ } \\
\text { Involvement }\end{array}$ & Criteria & \\
\hline \multirow[t]{2}{*}{$\begin{array}{l}\text { Musculo- } \\
\text { skeletal }\end{array}$} & $\begin{array}{l}\text { Polyarthralgia } \\
\text { Tenosynovitis }\end{array}$ & $\begin{array}{l}\text { Polyarthritis } \\
\text { Synovial effusion }\end{array}$ \\
\hline & \multicolumn{2}{|c|}{ Significant morning stiffness $(>30 \mathrm{~min})$} \\
\hline Cutaneous & \multicolumn{2}{|c|}{$\begin{array}{l}\text { Erythematous butterfly rash } \\
\text { Exclusions: Raynaud's phenomenon, } \\
\text { CDLE, photosensitivity, pigmentary changes, } \\
\text { leg ulcers,? digital gangrene }\end{array}$} \\
\hline Renal & \multicolumn{2}{|c|}{$\begin{array}{l}\text { Red cell or granular casts } \\
\text { Active involvement on histology } \\
\text { Significant or increasing proteinuria } \\
\text { Azotaemia } \\
\text { Increasing impairment of GFR }\end{array}$} \\
\hline Neurological & \multicolumn{2}{|c|}{$\begin{array}{l}\text { Recent neuropsychiatric manifestations } \\
\text { Recent focal neurological signs }\end{array}$} \\
\hline Serositis & $\begin{array}{l}\text { Pericarditis } \\
\text { Peritonitis }\end{array}$ & Pleurisy \\
\hline Haematological & \multicolumn{2}{|c|}{$\begin{array}{l}\text { Haemolytic anaemia } \\
\text { Thrombocytopenia }\left(<100 \times 10^{2} / 1\right) \\
\text { Leucopenia }\end{array}$} \\
\hline Constitutional & $\begin{array}{l}\text { Fever } \\
\text { Fatiguability }\end{array}$ & $\begin{array}{l}\text { Malaise } \\
\text { Weight loss }\end{array}$ \\
\hline
\end{tabular}

CDLE $=$ chronic discoid lupus erythematosus. $G F R=$ glomerular filtration rate.
SLE. (SI conversion: $\mu \mathrm{g} / \mathrm{ml}=\mathrm{mg} / \mathrm{l}$.) DNA immune complexes were measured by the millipore filtration and DNase digestion technique as described previously ${ }^{25}$ Where indicated, other investigations including full blood count, serum chemistry, tests of renal function, renal or other biopsies, radiological and neurological tests were performed.

The following correlations between the clinical evaluation and the serologic parameters were determined: (i) The clincal status and the $\mathrm{CH}_{50}$, ADA, and DNA-IC levels. For statistical purposes the clinical status was designated active or inactive, and each of the parameters as normal or abnormal by Haldane's modified formula ${ }^{30-32}$ This formula allows for normal and abnormal levels of each parameter in both active and inactive disease and also corrects for those instances where the numbers are small. (ii) The relationship between different grades of disease activity and actual DNA-IC levels was statistically evaluated, the null hypothesis being that the means of the DNA-IC levels in the different grades was equal, and the alternative hypothesis that the means were progressively higher for each grade of activity. (iii) The relationship between elevated levels of DNA-IC in patients with clinically inactive disease and the subsequent development of flares. In this instance actual DNA-IC levels and the grade of activity which ensued were evaluated.

\section{Results}

Of the 40 patients 15 remained clinically inactive during the 30 -month period of study, while in the remaining 25 patients 44 acute flares were recorded. In the latter group 13 were on corticosteroid and/or immunosuppressive therapy at the time of the flare. The dosage was increased in 9 patients to control symptoms, while corticosteroid therapy was begun in 9.

The clinical manifestations of the 25 patients who developed active disease and the relationship to circulating DNA-IC are shown in Table 2. Arthritis and skin involvement accounted for the majority of active episodes both when they occurred alone (12 and 11 episodes respectively) or when they occurred as part of a more general flare with other organ involvement (21 and 20 episodes respectively). One hundred and twenty nine single DNA-IC assays were performed, 76 during active and 53 during quiescent phases of the disease. In 2 patients several IC measurements were made over a 24 -hour period during active disease, and the mean of these levels was taken to represent the IC level for the particular episode. ADA levels were measured in 188 , and $\mathrm{CH}_{50}$ in 176 samples from the patients during the same period of study. The results obtained are shown in Table 3 . 
Table 2 Relationship of organ involvement to DNA-IC in 25 patients.

\begin{tabular}{|c|c|c|c|}
\hline $\begin{array}{l}\text { Organ } \\
\text { involvement }\end{array}$ & $\begin{array}{l}\text { No of active } \\
\text { episodes }\end{array}$ & $\begin{array}{l}\text { DNA-IC } \\
\text { present* }\end{array}$ & $\begin{array}{l}\text { Not } \\
\text { present }\end{array}$ \\
\hline Musculoskeletal & 12 & 16 & 7 \\
\hline Skin & 11 & 10 & 8 \\
\hline Renal & 5 & 2 & 5 \\
\hline Musculoskeletal/skin & 3 & 3 & 2 \\
\hline Skin/CNS & 2 & 4 & 1 \\
\hline \multicolumn{4}{|l|}{ Musculoskeletal/ } \\
\hline CNS/renal & 2 & 2 & 2 \\
\hline Skin/renal & 2 & 2 & 1 \\
\hline CNS & 1 & 1 & - \\
\hline \multicolumn{4}{|l|}{ Musculoskeletal/ } \\
\hline skin/renal & 1 & 2 & - \\
\hline Thrombocytopenia & 1 & 1 & - \\
\hline Pericarditis & 1 & - & 1 \\
\hline \multicolumn{3}{|l|}{ Musculoskeletal/ } & - \\
\hline \multicolumn{4}{|l|}{ Musculoskeletal/ } \\
\hline CNS/pleurisy & 1 & 2 & 1 \\
\hline \multicolumn{4}{|l|}{ Musculoskeletal/ } \\
\hline $\begin{array}{l}\text { Skın/renal/ } \\
\text { pericarditis/lung }\end{array}$ & $1^{\cdot}$ & $\cdot i$ & 1 \\
\hline Total & 44 & 47 & 29 \\
\hline
\end{tabular}

*Number of assays.

Abnormalities of the 3 parameters either singly or in combination were all significant as monitors for the presence of active disease. Depressed $\mathrm{CH}_{50}$ levels alone reflected disease activity more accurately than either ADA or DNA-IC. The combination of ADA + DNA-IC or $\mathrm{CH}_{50}$ +DNA-IC were significantly better predictors of activity than for any of the prameters singly or for the ADA $+\mathrm{CH}_{50}$ combination. The combination of all 3 parameters was superior to the ADA $+\mathrm{CH}_{50}$ combination but not to the $\mathrm{CH}_{50}+$ DNA-IC or ADA + DNA-IC combination as monitors of active disease. Furthermore it is noteworthy that $\mathrm{CH}_{50}$ as a single monitor was better than $\mathrm{ADA}+\mathrm{CH}_{50}$. Thus the most useful combination of parameters for assessing the relative risk of disease activity was, firstly, $\mathrm{CH}_{50}+\mathrm{DNA}-\mathrm{IC}$, followed by ADA + DNA-IC and ADA + $\mathrm{CH}_{50}+$ DNA-IC.

DNA-IC levels in active and inactive disease are shown in Fig. 1. The highest levels for inactive disease and for minor flares were 1.77 and 1.63 units $/ \mathrm{ml}$. respectively. Levels above $3.50 \mathrm{units} / \mathrm{ml}$ were found

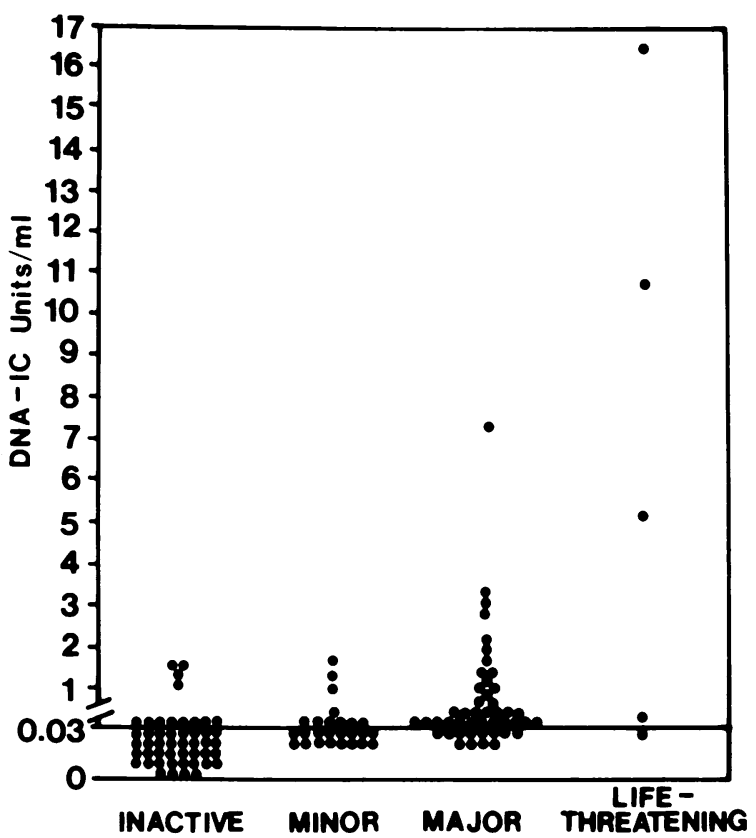

Fig. 1 DNA-IC levels in active and inactive SLE are shown. Complexes were undetectable in $36 / 52(69 \%)$ patients with inactive disease and in 16/26 (61\%) with minor, 12/46 (26\%) with major, and $1 / 5$ (20\%) with life-threatening disease.

Table 3 Relationship between clinically active and inactive SLE and the serological parameters $A D A, C H{ }_{50}$ and DNA-IC, singly and in combination together with the chi-square and $p$ values.

\begin{tabular}{|c|c|c|c|c|c|c|c|}
\hline \multirow{2}{*}{$\begin{array}{l}\text { Serological } \\
\text { parameter }\end{array}$} & \multicolumn{2}{|c|}{ Active disease } & \multicolumn{2}{|c|}{ Inactive disease } & \multirow{2}{*}{$\begin{array}{l}\text { Relative risk } \\
\text { of active disease }\end{array}$} & \multirow[t]{2}{*}{$x^{2}$} & \multirow[t]{2}{*}{$p$} \\
\hline & $\begin{array}{l}\text { Abnormal } \\
\%\end{array}$ & $\begin{array}{l}\text { Normal } \\
\%\end{array}$ & $\begin{array}{l}\text { Abnormal } \\
\%\end{array}$ & $\begin{array}{l}\text { Normal } \\
\%\end{array}$ & & & \\
\hline $\begin{array}{l}\text { ADA } \\
\mathrm{CH}_{50} \\
\text { DNA-IC } \\
\text { ADA }+\mathrm{CH}_{50} \\
\text { DNA-IC }+\mathrm{CH}_{50} \\
\text { ADA + DNA-IC } \\
\text { ADA + } \mathrm{CH}_{50}+ \\
\text { DNA-IC }\end{array}$ & $\begin{array}{l}69 \\
76 \\
62 \\
81 \\
86 \\
74 \\
85\end{array}$ & $\begin{array}{l}31 \\
24 \\
38 \\
19 \\
14 \\
26 \\
15\end{array}$ & $\begin{array}{l}51 \\
47 \\
32 \\
46 \\
32 \\
19 \\
22\end{array}$ & $\begin{array}{l}49 \\
53 \\
68 \\
54 \\
68 \\
81 \\
78\end{array}$ & $\begin{array}{r}2 \cdot 11 \\
3 \cdot 46 \\
3 \cdot 36 \\
4 \cdot 65 \\
11 \cdot 84 \\
10 \cdot 86 \\
16 \cdot 70\end{array}$ & $\begin{array}{r}6 \cdot 19 \\
14 \cdot 73 \\
10 \cdot 73 \\
14 \cdot 24 \\
19 \cdot 14 \\
18 \cdot 36 \\
16 \cdot 94\end{array}$ & $\begin{array}{l}0.009 \\
7.77 \times 10^{-5} \\
0.0008 \\
0.0001 \\
4.54 \times 10^{-6} \\
5.56 \times 10^{-6} \\
1.57 \times 10^{-5}\end{array}$ \\
\hline
\end{tabular}


only in patients with life-threatening disease with the exception of one patient with a major flare, in whom the level was 7.40 units $/ \mathrm{ml}$. An analysis of DNA-IC levels in the different grades of disease activity shows that, while the difference between DNA-IC levels in inactive disease compared to minor activity was not significant, the mean levels in the 3 groups, (1) inactive plus minor, (2) major, and (3) life-threatening activity, were significantly different at the 0.02 significance level. Allowance was made in the analysis for the small number of patients with life-threatening disease.

Eleven patients with raised DNA-ICs and clinically inactive disease were carefully observed for the subsequent development of active disease. The outcome is shown in Table 4 . Three patients did not develop any evidence of active disease over a 30 -month period of observation while $6(55 \%)$ had minor and $2(18 \%)$ had major flares. The onset of the active episodes ranged from 1 to 9 months. Of the 11 patients $6(55 \%)$ had unequivocal renal lupus histologically, and $2(18 \%)$ patients had had granular casts on a few occasions in the past. The remaining 3 patients at no stage showed any evidence of renal involvement.

Table 4 Outcome in 11 patients with SLE in whom DNA-IC was present without evidence of clinical activity

\begin{tabular}{|c|c|c|c|c|}
\hline \multirow[t]{2}{*}{ Patient } & \multirow{2}{*}{$\begin{array}{l}\text { DNA-IC } \\
\text { levels }\end{array}$} & \multirow{2}{*}{$\begin{array}{l}\text { Outcome } \\
\text { (months) }\end{array}$} & \multicolumn{2}{|c|}{ Severity of acute episode } \\
\hline & & & Minor & Major \\
\hline 1 & $1 \cdot 73$ & 4 & Polyarthralgia & \\
\hline 2 & $\begin{array}{l}0.03 \\
0.59\end{array}$ & $\begin{array}{l}2 \\
1\end{array}$ & & $\begin{array}{l}\text { Oral ulceration } \\
\text { Headache } \\
\text { Butterfly rash } \\
\text { Alopecia }\end{array}$ \\
\hline 3 & $\begin{array}{l}1 \cdot 17 \\
0 \cdot 04 \\
0 \cdot 19\end{array}$ & $\begin{array}{l}9 \\
7 \\
6\end{array}$ & Polyarthralgia & \\
\hline $4^{*}$ & $0 \cdot 28$ & 3 & Polyarthralgia & \\
\hline 5 & $\begin{array}{l}0 \cdot 25 \\
0 \cdot 02 \\
1 \cdot 68\end{array}$ & $\begin{array}{l}8 \\
7 \\
4\end{array}$ & Malaise & \\
\hline 6 & $0 \cdot 06$ & 2 & & $\begin{array}{l}\text { Skin vasculitis } \\
\text { Alopecia } \\
\text { Malaise }\end{array}$ \\
\hline 7 & $0 \cdot 60$ & 9 & Polyarthritis & \\
\hline 8 & $\begin{array}{l}1 \cdot 77 \\
0 \cdot 10\end{array}$ & $\begin{array}{l}2 \\
1\end{array}$ & Polyarthralgia & \\
\hline 9 & $0 \cdot 18$ & 30 & No act & tivity \\
\hline 10 & $0 \cdot 22$ & 30 & No act & tivity \\
\hline 11 & $0 \cdot 14$ & 30 & No act & tivity \\
\hline
\end{tabular}

*Died 11 months later from suspected cerebral lupus.

\section{Discussion}

The clinical assessment of active SLE is relatively straightforward in most cases, particularly when there is objective evidence of arthritis, pleurisy, or pericarditis, or when typical skin changes are present. However in the case of renal and neurological disease the clinical evaluation of disease activity may be extremely difficult. A number of schemes for the evaluation of activity in SLE have been devised, including the use of scoring indices, grades according to the degree of activity, criteria for major or minor flares, and schemes based on the need for increased steroid therapy to control symptoms. ${ }^{33-36}$ The system used in this study is based on these but with modifications. In our experience most minor flares can be controlled adequately without corticosteriod/ immunosuppressive therapy. Thus the need to begin steroid therapy, or to increase the dose in those patients on treatment, permits a reasonably clear differentiation between minor and major flares. The third category of patients, those presenting with lifethreatening disease, was included to study the role of the DNA-IC in this small but important group separately. No system for the assessment of activity is entirely satisfactory, since the evaluation is partly subjective. It is difficult to know whether Raynaud's phenomenon, leg ulcers, urticaria, and digital gangrene reflect active disease or not. To avoid so far as possible false positive assessments of activity these cutaneous manifestations were not included in the scheme. Red cell and granular casts suggest renal involvement. Their absence in the urine, however, does not exclude active renal disease. ${ }^{35}$ The same applies to proteinuria.

DNA-specific ICs have been shown to correlate with active disease..$^{23}{ }^{37}$ In these studies DNA-ICs were present in $58 \%$ of cases during acute episodes. This is in agreement with our data, where circulating compexes were detected in $62 \%$ of acute flares.

The correlation between the serological tests and clinical activity shows that $\mathrm{CH}_{50}$ is a better monitor of active SLE than either ADA or DNA-IC. The most likely explanation is that $\mathrm{CH}_{50}$ consumption occurs during the formation of any IC, which is complementfixing, and is independant of the antigen. There is evidence that both DNA and non-DNA-IC complexes are important in SLE. ${ }^{15}$ Some of these complexes are likely to be complement fixing, and it is therefore not surprising that depression of haemolytic complement is a good index of disease activity. It is not clear why the DNA-IC is a better indicator than ADA. The reason for this may be that ADA in itself is not capable of producing tissue damage, so that its presence in the circulation does not necessarily imply that ICs are being formed and deposited. Circulating 
compexes on the other hand, because of their potential to initiate tissue injury, are more likely to be associated with active disease.

The fact that $73 \%$ of patients with clinically inactive disease and raised IC values subsequently developed evidence of disease activity suggests that measurement of DNA-IC is of predictive value. It is not possible, however, to predict the nature or the severity of the attack from the levels of circulating complexes. These preliminary data suggest that patients should not be treated on the basis of raised IC levels alone but should be carefully observed for the development of clinically active disease. The possibility that subclinical renal activity might have been present in the patients with elevated DNA-IC levels in clinically inactive disease cannot be excluded. The important question whether elevated DNA-IC levels are a better monitor than $\mathrm{CH}_{50}$ or ADA for active renal disease can be resolved only by performing renal biopsies on all patients with increased IC levels whether or not there is evidence of renal activity at the time of analysis.

The difference in complex levels between inactive/minor, major, and life-threatening disease, after allowing for the fact that there were only 5 samples in the last group, was striking. The study thus shows that actual DNA-IC levels correlate with the severity of the acute episode.

We believe that this new technique for the measurement of specific DNA-ICs is a useful addition to the tests currently available for the diagnosis and assessment of activity in SLE. Apart from its specificity it is easy to perform, it does not require expensive or sophisticated equipment, and it can therefore easily be introduced as a routine assay in most laboratories.

\section{References}

1 Hargraves M M. Presentation of two bone marrow elements: The 'Tart' cell and the 'L E' cell. Mayo Clin Proc 1948; 23: 25-8.

2 Pincus T, Schur P H, Rose J A, Decker J L, Talal N. Measurement of serum DNA-binding activity in SLE. $N$ Engl $J$ Med 1969; 281: 701-5.

3 Hughes G R V. Significance of anti-DNA antibodies in systemic lupus erythematosus. Lancet 1971; ii: 861-3.

4 Hughes G R V, Cohen S A, Christian C L. Anti-DNA activity in systemic lupus erythematosus-a diagnostic and therapeutic guide. Ann Rheum Dis 1971; 30: 259-64.

5 Webb J, Whaley K, Lee P. Clinical significance of native DNA antibodies in systemic lupus erythematosus and other connective tissue diseases. Scot Med J 1974; 19:171-5.

6 Schur P H. Complement in lupus. Clin Rheum Dis 1975; 1: $519-43$.

7 Slater N G P, Cameron J S, Lessof M H. The Crithidia luciliae kinetoplast immunofluorescence test in systemic lupus erythematosus. Clin Exp Immunol 1976; 25: 480-6.

8 Whaley K, Hughes G R V, Webb J. Systemic lupus erythematosus in man and animals. In: Buchanan W W, Dick W C, eds. Recent Advances in Rheumatology. Part I. Underlying Mechan- isms of Disease. Edinburgh, London, and New York: Churchill Livingstone, 1976: 67-136.

9 Shulman N R, Barker L F. Virus-like antigen, antibody and antigen-antibody complexes in hepatitis measured by complement fixation. Science 1969; 165: 304-6.

10 Winchester R J, Kunkel H G, Angello V. Occurrence of gammaglobulin complexes in serum and joint fluid of rheumatoid arthritis patients: use of monoclonal rheumatoid factors in reagents for their demonstration.J Exp Med 1971134 (suppl): 286-95.

11 Penttinen K, Vaheri A, Myllylä G. Detection and characterisation of immune complexes by the platelet aggregation test. I. Complexes formed in vitro. Clin Exp Immunol 1971; 8: 389-97.

12 Nydegger U E, Lambert P H, Gerber H, Miescher P A. Circulating immune complexes in the serum in systemic lupus erythematosus and in carriers of hepatitis B antigen. Quantitation by binding to radiolabelled C1q. J Clin Invest 1974; 54: 297-309.

13 Theofilopoulos A N, Wilson C B, Bokisch V A, Dixon F J. Binding of soluble immune complexes to human lymphoblastoid cells. II. Use of Raji cells to detect circulating immune complexes in animal and human sera. $J$ Exp Med 1974; 140: $1230-44$.

14 Johnson A H, Mowbray J F, Porter K A. Detection of circulating immune complexes in pathological human sera Lancet 1975; i: 762-5.

15 Bruneau C, Edmonds J P, Hughes G R V. Circulating complexes and disease activity in SLE. Ann Rheum Dis 1975; 34: 469.

16 Sobel A T, Bokisch V A, Müller-Eberhard H J. C1q deviation test for the detection of immune complexes, aggregates of IgG and bacterial products in human sera. $J$ Exp Med 1975; 142: 139-50.

17 Bruneau C D, Edmonds J P, Hughes G R V, Aarden L. Detection and characterisation of DNA: anti-DNA complexes in a patient with systemic lupus erythematosus. Clin Exp Immunol 1977; 28: 433-6.

18 Anan S, Renoux M L, Detection of circulating immune complexes in lupus erythematosus by precipitation test with polyethylene glycol and complement consumption test (author's transl). Ann Dermatol Venereol 1977; 104: 446-52.

19 Cano P O, Jerry L M, Sladowski J P, Osterland C K. Circulating immune complexes in systemic lupus erythematosus. Clin Exp Immunol 1977; 29: 197-204.

20 Cambiaso C L, Riccomi H, Masson P L. Automated determination of immune complexes by their inhibitory effect on the agglutination of IgG-coated particles by rheumatoid factor or C1q. Ann Rheum Dis 1977; 36 (suppl 1): 40-4.

21 Tung K S K, Woodroffe A J, Ahlin T D, Williams R C, Wilson C B. Application of the solid phase $\mathrm{C} 1 \mathrm{q}$ and Raji cell radioimmune assays for the detection of circulating immune complexes in glomerulonephritis. J Clin Invest 1978; 62: 61-72.

22 Harbeck R J, Bardana E J, Kohler F, Carr R I. DNA-anti-DNA complexes: their detection in systemic lupus erythematosus sera. J Clin Invest 1973; 52: 789-95.

23 Carr R I, Harbeck R J, Hoffman A A, Pirofsky B, Bardana E J. Clinical studies on the significance of DNA: anti-DNA complexes in the systemic circulation and cerebrospinal fluid (CSF) of patients with systemic lupus erythematosus. $J$ Rheumatol 1975; 2: 184-93.

24 Waller S J, Taylor R P, Wright E L, Morley K W, Johns M. DNA/anti-DNA complexes: correlation of size and complement fixation. Ann Rheum Dis 1981; 24: 651-7.

25 Harley E H, Klemp P. A specific DNA immune complex assay and its application in SLE. Clin Chim Acta 1982; 122: 213-23.

26 Botha M C, Pritchard J. Blood group gene frequencies. An indication of the genetic constitution of population samples in Cape Town. S Afr Med J 1972; 46 (suppl): 1-27.

27 Cohen A S, Reynolds W E, Franklin E C, et al. Preliminary criteria for the classification of systemic lupus erythematosus. Bull Rheum Dis 1971; 21: 643-8. 
28 Kent J F, Bukantz S C, Rein C R. Studies in complement fixation. I. Spectophotometric titration of complement; construction of graphs for direct determination of the 50 per cent haemolytic unit. J Immunol 1946; 53: 37-50.

29 Ginsberg B, Keiser H. A millipore filter assay for antibodies to native DNA in sera of patients with systemic lupus erythematosus. Arthritis Rheum 1973; 16: 199-207.

30 Haldane J B S. The estimation and significance of the logarithm of a ratio of frequencies. Ann Hum Genet 1955; 20: 309-11.

31 Svejgaard A, Jersild C, Staub Nielson L, Bodmer W F. HLA antigens and disease: statistical and genetical considerations. Tissue Antigens 1974; 4: 95-105.

32 Briggs B R, Jackson W P U, Du Toit E D, Botha M C. The histocompatibility (HLA) antigen distribution in diabetes in Southern African blacks (Xhosa). Diabetes 1980; 29: 68-70.
33 Schur P H, Sandson J. Immunological factors and clinical activity in systemic lupus erythematosus. $N$ Engl $\mathrm{J}$ Med 1968 278: 533-8.

34 Lightfoot $\mathbf{R ~ W , ~ H u g h e s ~ G ~ R ~ V . ~ S i g n i f i c a n c e ~ o f ~ p e r s i s t i n g ~}$ serologic abnormalities in SLE. Arthritis Rheum 1976; 19: 837-43.

35 Ropes M W. Systemic Lupus Erythematosus. Cambridge, Massachusetts, and London: Havard University Press, 1976: 1-12.

36 Rivero S J, Diaz-Jouanen E, Alarcon-Segovia D. Lymphopenia in systemic lupus erythematosus. Arthritis Rheum 1978; 21: 295-305.

37 Bardana E J, Harbeck R J, Hoffman A A, Pirofsky B, Carr R I. The prognostic and therapeutic implications of DNA: anti-DNA immune complexes in systemic lupus erythematosus (SLE). Am J Med 1975; 59: 515-22. 